\title{
Pengaruh Edukasi Gizi terhadap Praktik Pemberian Makan Pada Baduta Stunting di Kabupaten Bengkulu Utara
}

\author{
Agus Sri Banowo ${ }^{1 *}$, Yance Hidayat ${ }^{2}$ \\ ${ }^{1}$ Bagian Keperawatan Komunitas dan Jiwa, Fakultas Keperawatan, Universitas Andalas \\ ${ }^{2}$ S2 Keperawatan Peminatan Keperawatan Komunitas, Fakultas Keperawatan Universitas Andalas \\ *Correspondence email: banowo_agussri@nrs.unand.ac.id
}

\begin{abstract}
Abstrak. Stunting merupakan masalah gizi kurang yang kronis. Praktik pemberian makan merupakan salah satu faktor yang berkontribusi terhadap kejadian stunting, sehingga diperlukan adanya edukasi gizi mengenai praktik pemberian makan. Tujuan dilakukannya penelitian adalah mengetahui pengaruh intervensi edukasi gizi terhadap praktik pemberian makan ibu yang memiliki baduta stunting. Desain penelitian menggunakan desain quasi experiment dengan pre-post test two group design. Lokasi penelitian adalah puskesmas Kerkap sebagai intervensi dan puskesmas Air Lais sebagai kontrol dengan jumlah sampel masingmasing 40 orang. Uji yang digunakan dalam penelitian ini adalah uji paired sampel $t$ test dan uji $t$-independent. Hasil uji dependent terdapat perbedaan rata-rata praktik pemberian makan antara kelompok kontrol dan intervensi dengan nilai $p$ value 0,000 dan 0,168, dan uji independen antara kelompok intervensi dan kelompok kontrol 0,000. Edukasi gizi sebagai program unggulan sehingga dapat meningkatkan praktik pemberian makan keluarga terhadap anak stunting.
\end{abstract}

Kata Kunci: Edukasi Gizi, Praktik Pemberian Makan, Stunting.

Abstract. Stunting is a less chronic nutritional problem. The practice of feeding is one of the factors that contribute to stunting, so there is a need for nutrition education regarding the practice of providing food. This study aims to discuss nutrition education interventions on the practice of feeding mothers who have stunting. The study design used a quasi-experimental design with a pre-posttest design of two groups. The research location was Kerkap health centre as an intervention and Air Lais health centre as a control with a sample of 40 people each. The test used in this study paired-sample t-test and independent t-test. The different tests' results depend on the average meal management between the control groups and comparison with $p$ values of 0,000 and 0.168, and independent tests between the intervention group and the control group of 0,000. Nutrition education is a particular program to improve the practice of family feeding of stunting children.

Keywords: Stunting, Nutrition Education, Feeding Practices

\section{PENDAHULUAN}

Masalah gizi masih menjadi masalah yang besar karena berkaitan erat dengan indikator kesehatan umumnya seperti tingginya angka kesakitan serta angka kesakitan bayi dan balita (WHO, 2017). Pembangunan kesehatan dalam periode 2015-2019 difokuskan pada empat program prioritas yaitu penurunan angka kematian ibu dan bayi, penurunan prevalensi balita pendek (stunting), pengendalian penyakit menular dan pengendalian penyakit tidak menular (Kemenkes, 2016). Upaya peningkatan status gizi masyarakat termasuk pembangunan nasional, salah satunya adalah penurunan prevalensi stunting (pendek dan sangat pendek) pada anak dibawah usia dua tahun (Coffey et al., 2015).

Stunting merupakan kondisi kronis yang menggambarkan terhambatnya pertumbuhan karena malnutrisi jangka panjang. Stunting menurut WHO Child Growth Standart didasarkan pada indeks panjang badan dibandingkan dengan umur $(\mathrm{PB} / \mathrm{U})$ atau tinggi badan dibandingkan dengan umur (TB/U) dengan batas $(z-$ score) kurang dari -2 SD (WHO, 2005). Stunting merupakan refleksi jangka panjang dari kualitas dan kuantitas makanan yang tidak memadai dan sering menderita infeksi selama masa kanak-kanak (Perezescamilla dan Moran, 2017). Stunting pada balita perlu menjadi perhatian khusus karena dapat menghambat perkembangan fisik dan mental anak dan berkaitan dengan resiko kesakitan dan kematian serta terhambatnya pertumbuhan kemampuan motorik dan mental (Purwandini, 2013). Balita yang Stunting memiliki resiko terjadinya penurunan kemampuan intelektual, produktivitas, dan peningkatan resiko penyakit degeneratif dimasa mendatang (Saaka \& Galaa, 2016).

Hasil Riset Kesehatan Dasar (Riskesdas) (Kemenkes, 2013) prevalensi balita stunting di Indonesia adalah $37,2 \%$, jika dibandingkan tahun 2010 $(35,6 \%)$ dan tahun 2007 (36,8\%) tidak menunjukkan penurunan/perbaikan yang signifikan. Persentase tertinggi pada tahun 2013 adalah di provinsi Nusa Tenggara Timur $(51,7 \%)$, Sulawesi Barat $(48,0 \%)$ dan Nusa Tenggara Barat $(45,3 \%)$ sedangkan persentase terendah adalah Provinsi Kepulauan Riau (26,3\%), DI Yogyakarta (27,2\%) dan DKI Jakarta (27,5\%).

Banyak faktor yang mempengaruhi stunting, diantaranya adalah panjang badan lahir, status ekonomi keluarga, tingkat pendidikan dan tinggi badan orang tua. Panjang badan lahir pendek merupakan salah satu faktor resiko stunting pada balita. Panjang badan lahir pendek bisa disebabkan oleh faktor genetik yaitu tinggi badan 
orang tua yang pendek maupun kurangnya pemenuhan zat gizi selama masa kehamilan (Sujendran, Senarath, \& Joseph, 2015). Panjang badan lahir pendek pada anak menunjukkan kurangnya zat gizi yang diasup ibu selama kehamilan, sehingga pertumbuhan janin yang tidak optimal yang mengakibatkan bayi yang lahir memiliki panjang badan lahir pendek. (De Onis \& Branca, 2016).

Selain panjang badan lahir dan tinggi badan orang tua, status ekonomi keluarga dan pendidikan orang tua juga merupakan faktor resiko kejadian stunting pada balita. Status ekonomi keluarga dipengaruhi oleh beberapa faktor, antara lain pekerjaan orang tua, tingkat pendidikan orang tua dan jumlah anggota keluarga. Status ekonomi keluarga akan mempengaruhi kemampuan pemenuhan gizi keluarga maupun kemampuan mendapatkan layanan kesehatan. Anak pada tingkat ekonomi rendah lebih berisiko mengalami stunting karena kemampuan pemenuhan gizi yang rendah meningkatkan risiko terjadinya malnutrisi (Demirchyan, Petrosyan, Sargsyan, \& Hekimian, 2016). Tingkat pendidikan orang tua yang rendah juga disinyalir meningkatkan risiko malnutrisi pada anak. Tingkat pendidikan orang tua berpengaruh terhadap pengetahuan orang tua terkait gizi dan pola pengasuhan anak, dimana pola asuh yang tidak tepat akan meningkatkan risiko kejadianmstunting. (Handayani, et al., 2017).

Pola asuh ibu dalam memberikan makan dipengaruhi oleh ketersediaan pangan dan tingkat pengetahuan ibu tentang gizi. Ibu dalam proses pemberian makan kepada anak dituntun untuk sabar karena sering ditemui anak yang tidak mau makan. Kreatifitas ibu dalam memberi makan juga sangat diperlukan, ibu dituntut untuk menciptakan kreasi makanan yang menarik atau menimbulkan nafsu makan anak. hal ini akan terlihat pada makanan yang diberikan tidak monoton.

Penelitian menyebutkan adanya hubungan yang nyata antara pola asuh dengan stunting (Ohyver et al., 2017). Perilaku pemberian makanan balita dipengaruhi oleh pengetahuan gizi ibu. Pengetahuan gizi ibu adalah salah satu faktor yang mempunyai pengaruh signifikan pada kejadian stunting (Handayani, et al, 2017). Oleh karena itu, upaya perbaikan stunting dapat dilakukan dengan peningkatan pengetahuan sehingga dapat memperbaiki prilaku pemberian makan pada anak, maka asupan makan anak juga dapat diperbaiki yaitu dengan edukasi gizi.

Berdasarkan Profil Dinas Kesehatan Provinsi Bengkulu pada tahun 2015, 2016, dan 2017 mengalami peningkatan angka stunting yaitu $18,1 \%$, $23,0 \%$ dan $29,5 \%$. Kabupaten Kaur merupakan angka tertinggi diprovinsi Bengkulu pada tahun 2013 berdasarkan riskesdas dengan angka stunting 50,71\% dan termasuk kedalam 100 kabupaten/kota di Indonesia dengan prioritas dalam pengobatan Stunting, pada tahun 2017 angka tersebut menurun menjadi 23,7\%.

Hasil Pemantauan Status Gizi (PSG) berdasarkan indeks $\mathrm{TB} / \mathrm{U}$ (stunting) menurut kabupaten kota di provinsi Bengkulu pada tahun 2015 sampai 2017, angka tertinggi adalah kabupaten Bengkulu Utara yaitu 35,8\%, kemudian disusul oleh Bengkulu Tengah 34,8\% dan Kabupaten Lebong 34,4\%. Kabupaten Bengkulu Utara menjadi salah satu dari 60 Kabupaten/Kota tambahan prioritas penanggulangan stunting pada tahun 2019.

Kebiasaan makan masyarakat Bengkulu Utara rata-rata mengkonsumsi makanan padat energi seperti nasi, sayur sebagai sumber serat. Pola makan masyarakat juga pada umumnya hanya terbatas pada dua sampai tiga kali makan utama tanpa ada selingan. Pada umumnya masyarakat di Kabupaten ini memiliki sumber pangan yang sangat kaya dengan protein yang berasal dari ikan, mengingat letak kabupaten Bengkulu Utara ditepi laut dan sebagian masyarakat berprofesi sebagai nelayan, kebiasaan masyarakat lebih memilih menjual hasil tangkapannya dari pada untuk konsumsi. Kebiasaan makan seperti ini banyak ditemui dimasyarakat yaitu pola pemberian makan pada anak sebanyak 3 kali makan utama dengan jenis asupan tinggi energi. Pola pemberian makan ini tidak memperhatikan kebutuhan zat gizi yang penting bagi pertumbuhan balita sehingga kemungkinan kebiasaan tersebut berdampak pada status gizi balita

Stunting menjadi permasalahan gizi jangka panjang dan merupakan pertumbuhan yang terjadi secara permanen atau sulit untuk diperbaiki kembali. Stunting juga merupakan masalah multi-kausal akibat dari proses kumulatif retardasi pertumbuhan. Dampak stunting adalah terhambatnya perkembangan otak dan fisik, rentan terhadap penyakit, menghambat pertumbuhan ekonomi, meningkatkan angka kemiskinan dan kesakitan sehingga beban negara meningkat dan menurunkan daya saing dengan negara lain.

Praktek pemberian makan merupakan salah satu faktor yang berkontribusi terhadap kejadian stunting, sehingga diperlukan adanya edukasi gizi mengenai praktek pemberian makan. Intervensi edukasi mencakup pengetahuan, dan pemberian motivasi kearah perubahan sikap dan perilaku pemberian makan.

\section{METODE}

Desain penelitian menggunakan desain quasi experiment dengan menggunakan rancangan two group pre and post test design, yaitu rancangan sebelum dan sesudah intervensi menggunakan dua kelompok. Rancangan penelitian ini dilakukan pengujian pertama (pre test) yang diberikan kepada kelompok eksperimen, setelah itu peneliti melakukan intervensi terhadap responden yang selanjutnya dilakukan pengujian 
kembali (post test) untuk mengevaluasi dampak edukasi gizi terhadap praktik pemberian makan baduta stunting.

\begin{tabular}{|c|c|c|}
\hline Pretest & Perlakuan & Posttest \\
\hline $\mathrm{O}_{1}$ & $\rightarrow \mathrm{X}-$ & $\mathrm{O}_{2}$ \\
\hline $\mathrm{O}_{3}$ & & $\mathrm{O}_{4}$ \\
\hline
\end{tabular}

Gambar 1. Model rancangan penelitian dengan metode quasi eksperimen

Keterangan

$\mathrm{O}_{1}$ : Pre test untuk mengetahui praktik pemberian makan keluarga pada baduta stunting usia sebelum perlakuan

$X$ : Intervensi berupa edukasi gizi yang diberikan selama 3 kali pertemuan

$\mathrm{O}_{2}$ : Post test untuk mengetahui praktik pemberian makan keluarga pada baduta stunting setelah intervensi

O3 : Pre test untuk mengetahui praktik pemberian makan keluarga pada baduta stunting pada kelompok kontrol

O4 : Post test untuk mengetahui praktik pemberian makan keluarga pada baduta stunting pada kelompok kontrol

Populasi responden dalam penelitian ini adalah ibu dan anak baduta yang mengalami stunting di dua puskesmas dengan angka tertinggi yang tercatat pada "Hasil Pemantaun Status Gizi" pada bulan Juni 2018 di Kabupaten Bengkulu Utara. Berdasarkan hal tersebut tercatat Puskesmas Kerkap dengan 143 anak dan Puskesmas Air Lais dengan 124 anak sebagai populasi dalam penelitian ini. Total seluruh populasi berjumlah 267 anak. Sampel dalam penelitian ini ditentukan dengan perhitungan sampel quasi eskperimen menurut rumus Lemeshow et al. (1990) yaitu sebagai berikut:

$n=\frac{2 \sigma^{2}\left(Z_{1}-\alpha+Z_{1}-\beta\right)^{2}}{\left(\mu_{1}-\mu_{2)}{ }^{2}\right.}$

Keterangan:

$\mathrm{n} \quad$ : Besar sampel minimum

$\sigma \quad$ : Standar deviasi 8

$\mu \quad$ : Rata-rata 18

$\mathrm{Z}_{1}-\alpha \quad$ : Kurva normal tingkat kesalahan yang ditentukan dalam penelitian $(\alpha: 5=1,96)$

Z1- $\beta$ : Nilai $Z$ pada kekuatan $1-\beta$ adalah $0,84(\beta=$ $80 \%)$

Berdasarkan rumus diatas, jumlah sampel penelitian quasi eksperimen adalah 28 responden, dengan menambahkan $10 \%$ untuk mencegah terjadinya drop out sampel. Penentuan responden menggunakan Probability Sampling dengan teknik Multi Stage Sampling yaitu teknik sampling yang dilakukan ditingkat wilayah secara bertahap. Responden dalam penelitian ini harus memenuhi kriteria inkulisi sebagai berikut: a) Usia Baduta 7-24 bulan, b) Stunting (z score PB/U kurang dari -2SD), c) Berdomisili di Kabupaten Bengkulu Utara, d) Bersedia menjadi subjek penelitian (menanda tangani informed concent), e) Responden dapat berkomunikasi dengan baik. Sedangkan, yang menjadi kriteria ekslusi dalam penelitian ini adalah: a) Ibu dan anak sakit sehingga tidak bisa hadir pada saat intervensi berlangsung, b) Ibu berpindah tempat tinggal selama penelitian berlangsung, c) Tidak mendapatkan intervensi secara lengkap

Penelitian ini dilaksanakan Maret 2018 sampai dengan 31 Juli 2019. Penelitian ini juga sudah memenuhi kode etik penelitian (Informed Concent, Anonimity, Confidentialy, Menghormati keadilan dan keterbukaan).

Data diukur menggunakan kuesioner yang terdiri dari kuesiner I, II, dan III. Kuesioner I mengukur identitas responden (ibu) yang meliputi nama, alamat, umur, pendidikan, status pekerjaan dan penghasilan keluarga. Kuesioner II mengukur identitas baduta yang meliputi nama, jenis kelamin, tanggal lahir, umur, berat badan, tinggi badan dan tanggal penimbangan. Kuesioner III berisi pernyataan berskala lickert terkait praktik pemberian makan pada anak baduta stunting meliputi penyusunan menu, pengolahan bahan, penyajian dan cara pemberian. Kuesioner praktik pemberian makan merupakan instrumen baku Comprehensive Feeding Practice Questionnaire (CFPQ) yang diperkenalkan oleh Musher-Eizenman dan Holub (2007) yang telah dimodifikasi dan disesuaikan dengan kondisi masyarakat Indonesia.

Data yang diperoleh, dianalisis secara deskriptif kuantitatif (editing, coding, dan entri data (Notoatmodjo, 2012). Analisa data diawali dengan uji normalitas yang kemudian dilanjutkan dengan analisa univariat.

\section{HASIL DAN PEMBAHASAN Karakteristik Responden}

Karakteristik responden berdasarkan usia ibu, pendidikan ibu, pekerjaan ibu, dan penghasilan keluarga dapat dilihat pada Tabel 1 sebagai berikut:

Tabel 1. Karakteristik ibu yang mempunyai anak baduta stunting

\begin{tabular}{lcccc}
\hline \multirow{2}{*}{\multicolumn{1}{c}{ Variabel }} & \multicolumn{4}{c}{ Kelompok } \\
\cline { 2 - 5 } & \multicolumn{2}{c}{$\begin{array}{c}\text { Kontrol } \\
(\mathrm{n}=40)\end{array}$} & \multicolumn{2}{c}{$\begin{array}{c}\text { Intervensi } \\
(\mathrm{n}=40)\end{array}$} \\
\cline { 2 - 5 } & $\mathrm{f}$ & $\%$ & $\mathrm{f}$ & $\%$ \\
\hline Usia Ibu & & & & \\
- Dewasa Muda (18-40) & 38 & 95,5 & 37 & 92,5 \\
- Dewasa Tua (>40) & 2 & 5 & 3 & 7,5 \\
\hline Pendidikan Ibu & & & & \\
- Pendidikan Dasar & 16 & 40 & 17 & 42,5 \\
- Pendidikan Lanjut & 24 & 60 & 23 & 57,5 \\
\hline Status Pekerjaan Ibu & & & & \\
- Tidak Bekerja & 23 & 57,5 & 26 & 65 \\
- Bekerja & 17 & 42,5 & 14 & 35 \\
\hline Penghasilan Keluarga & & & & \\
$\quad$ - Tidak Mampu & 15 & 37,5 & 16 & 40 \\
$\quad$ - Mampu & 25 & 62,5 & 24 & 60 \\
\hline$\quad$
\end{tabular}

Berdasarkan Tabel 1, usia ibu yang menjadi respoden berada pada usia dewasa muda sebanyak 
95,5\% pada kelompok kontrol dan $92,5 \%$ pada kelompok intervensi. Indikator umur adalah faktor yang mempengaruhi pemenuhan gizi anak. Semakin tua umur seseorang maka proses perkembangan mental akan menjadi baik, intelegensi atau kemampuan untuk belajar dan berfikir dan menyesuaikan diri dalam situasi baru, kemudian lingkungan dimana seseorang dapat mempelajari hal-hal baik juga buruk tergantung pada sifat kelompoknya (Notoadmojo, 2012). Hal ini menunjukkan kemampuan orang tua dalam menerapkan pola asuh pada anaknya. Pola asuh ibu memiliki peran penting dalam kejadian stunting karena asupan makanan pada anak sepenuhnya diatur oleh ibunya. Ibu yang menerapkan pola asuh yang baik akan cenderung memiliki anak dengan status gizi yang baik pula, sebaliknya ibu yang menerapkan pola asuh kurang baik cenderung memiliki anak dengan status gizi yang kurang (Gibney et al., 2009).

Pada aspek pendidikan, sebagian responden ibu berpendidikan lanjut sebanyak 60,0\% pada kelompok kontrol dan 57,5\% kelompok intervensi. Tingkat pendidikan dari orang tua akan mempengaruhi kesehatan dan kesejahteraan anak. Ibu yang memiliki pendidikan lanjut akan mempunyai kesempatan yang lebih jelas dalam menyerap informasi bila dibandingkan dengan ibu yang berpendidikan dasar. Semakin tinggi pendidikan seseorang maka semakin bagus pola pikir dalam mencerna informasi yang akan mendasari individu dalam berprilaku. Hasil penelitian Alzaheb (2016) menunjukkan bahwa pendidikan memberikan hubungan yang kuat dengan praktik pemberian Makanan Pendamping Air Susu Ibu (MP-ASI).

Pada status pekerjaan menunjukkan sebagian besar responden tidak bekerja yakni sebanyak $57,5 \%$ responden pada kelompok kontrol dan sebanyak 65,0\% responden pada kelompok intervensi. Pekerjaan bukan merupakan hambatan bagi ibu dalam memberikan makan pada anak, karena ibu yang tidak bekerja tidak selamanya memberikan makan pada anak tepat pada waktunya. Hal ini ditunjukkan dari hasil penelitian bahwa lebih dari sebagian ibu tidak bekerja namun masih memiliki anak yang stunting. Ibu yang tidak bekerja beranggapan memberikan makan kepada anak tidak perlu tepat waktu asalkan anaknya kenyang dan tidak rewel, dengan alasan inilah membuat kebutuhan gizi anak tidak tercukupi dari makanan (Marfuah et al., 2017).

Aspek penghasilan keluarga menunjukkan $62,5 \%$ ibu responden pada kelompok kontrol dan $60,0 \%$ pada kelompok intervensi berada pada kalangan mampu. Keluarga dengan keadaan sosial ekonomi yang tidak mampu dan jumlah anggota keluarga yang banyak akan mengakibatkan kebutuhan primer seperti makanan, sandang, dan kebutuhan perumahan jadi sulit terpenuhi. Semakin besar pengeluaran pangan dalam rumah tangga menunjukkan semakin rendahnya ketahan pangan rumah tangga tersebut, hal tersebut dikaitkan dengan kemampuan dalam mengakses pangan. Bertambahnya pengeluaran untuk konsumsi tidak selalu diikuti dengan perbaikan pola konsumsi pangan (Fikadu et al., 2014). Meskipun seseorang cenderung menghabiskan sebagain besar pendapatannya untuk pangan, namun hal tersebut belum tentu mencerminkan kualitas gizi pangan yang dikonsumsi sudah memenuhi standar nilai gizi dengan baik.

\section{Rataan Praktik Pemberian Makan}

Distribusi rata-rata praktik pemberian makan yang diberikan ibu pada anak pada kelompok kontrol dan kelompok intervensi dapat dilihat pada Tabel 2 sebagai berikut:

Tabel 2. Distribusi Rata-rata Praktik Pemberian Makan saat Pre test dan Post test pada kelompok intervensi dan kontrol

\begin{tabular}{lllllllll}
\hline \multirow{2}{*}{ Variabel } & \multicolumn{4}{c}{ Kelompok Kontrol } & \multicolumn{3}{c}{ Kelompok Intervensi } \\
\cline { 2 - 8 } & Mean & SD & Min-Max & 95\%CI & Mean & SD & Min-Max & 95\%CI \\
\hline Pre test & 24,30 & 2,041 & $20-29$ & $23,65-24,95$ & 26,53 & 1,694 & $24-29$ & $25,98-27,07$ \\
Post test & 24,43 & 1,738 & $20-28$ & $23,87-24,98$ & 32,58 & 3,145 & $26-38$ & $31,57-33,58$ \\
\hline
\end{tabular}

Tabel 2 menunjukkan praktik pemberian makan sebelum intervensi pada kelompok kontrol dengan ratarata 24,30 atau $57 \%$ dari nilai total maksimal praktik pemberian makan, sedangkan pada kelompok intervensi dengan rata-rata 26,53 atau $64 \%$ dari total maksimal nilai praktik pemberian makan. Setelah intervensi terjadi kenaikan rerata praktik pemberian makan pada kelompok kontrol dan intervensi masing pada kelompok kontrol $1 \%$ dan pada kelompok intervensi $14 \%$.

Praktik pemberian makan saat pre test kelompok kontrol mengalami skor terendah pada pernyataan "pemanfaatan pangan lokal yang berada disekitar yang masih kurang dimanfaatkan oleh ibu". Sedangkan pada kelompok intervensi skor terendah pada terjadi pada pernyataan "penyusunan menu makanan yaitu pada pertanyaan sebelum memberikan makan ibu menghitung nilai gizi makanan yang akan diberikan kepada anaknya".

Hasil penelitian menunjukkan responden tidak memperhatikan nilai gizi pada anaknya, hal ini ditunjukkan dengan ibu memberikan makanan pada anaknya sesuai dengan makanan kesukaan anaknya. Ibu beranggapan makan banyak walaupun belum sesuai dengan nilai kebutuhan gizi maka anak sudah makan dengan baik. Hal ini harusnya menjadi perhatian Ibu dalam pemenuhan zat gizi pada sang anak, terutama zat gizi yang terkait dengan pertumbuhan seperti protein. Kekurangan zat gizi protein akan menyebabkan 
terhambatnya pertumbuhan tubuh kembang sang anak sehingga akan menjadikan anak pendek.

Hasil penelitian menunjukkan nilai rata-rata praktik pemberian makan pada saat post test pada kelompok kontrol adalah 24,43 dengan nilai terendah 20 dan nilai tertinggi 28 , sedangkan nilai rata-rata praktik pemberian makan pada saat post test pada kelompok intervensi adalah 32,58 dengan nilai terendah 26 dan tertinggi 38. Hal ini menunjukkan bahwa nilai praktik pada kelompok intervensi mengalami peningkatan.

Pemberian makanan yang adekuat akan memberikan kontribusi yang baik terhadap status gizi anak sedangkan pemberian makanan yang tidak memadai akan meyebabkan masalah kesehatan pada anak usia 6-23 bulan (Rocky, Rahman and Khan, (2016); and Heidkam et al, (2015)).

Selain itu, praktik pemberian makan pada anak stunting sebaiknya juga memfokuskan pada frekuensi pemberian makan ringan dan pemanfaatan pangan lokal yang banyak tersedia di sekitar. Makanan ringan dan aneka ragam pangan lokal tersebut perlu disesuaikan dengan kebutuhan dan tingkat usia anak.

\section{Uji Beda Praktik Pemberian Makan pada Baduta Stunting}

Hasil analisis bivariat menunjukkan perbedaan rata-rata praktik pemberian makan pada baduta stunting sebelum dan sesudah diberi edukasi gizi, baik pada kelompok kontrol maupun pada kelompok intervensi. Hal ini dapat dilihat pada Tabel 3 sebagai berikut:

Tabel 3. Perbedaan rata-rata praktik pemberian makan pada baduta stunting sebelum dan sesudah diberi edukasi gizi

\begin{tabular}{lccccc}
\hline \multicolumn{1}{c}{ Variabel } & Mean & SD & SE & P Value & N \\
\hline Pre Kontrol & 24,30 & 3,041 & 0,323 & 0,168 & 40 \\
Post Kontrol & 24,43 & 1,738 & 0,275 & & \\
Pre Intervensi & 26,53 & 1,694 & 0,268 & 0,000 & 40 \\
Post Intervensi & 32,58 & 3,145 & 0,497 & & \\
\hline
\end{tabular}

Berdasarkan hasil penelitian mengenai uji beda edukasi gizi sebelum dan sesudah terhadap praktik pemberian makan dengan menggunakan uji $t$ dependen didapatkan $p$ value kelompok intervensi 0,000, sedangkan pada kelompok kontrol 0,168. Berdasarkan hasil tersebut dapat diartikan terdapat pengaruh pemberian edukasi gizi terhadap praktik pemberian makan sebelum dan sesudah diberikan intervensi.

Hasil penelitian Arini et al., (2017) menunjukkan hasil yang sama terdapat perbedaan yang signifikan antara praktik setelah diberikan edukasi kelompok intervensi dan kelompok kontrol. Hal yang sama juga ditemukan pada penelitian Mulualem et al., (2016) dimana terdapat perbedaan rata-rata praktik pmeberian makan pada kelompok intervensi dan kelompok kontrol sesudah diberikan intervensi edukasi gizi.

Hardiansyah dan Supriansyah (2016) menyatakan edukasi gizi dapat diberikan dengan menggunakan berbagai macam media yaitu media auditif, visual, dan audiovisual. Media edukasi digunakan sebagai alat atau proses pembelajaran. Media memperjelas informasi agar tidak terlalu verbal, mengatasi masalah keterbatasan tempat, indera, waktu dan meningkatkan minat untuk belajar.

Intervensi edukasi gizi mencakup pemberian pengetahuan dan pemberian motivasi ke arah perubahan sikap dan perilaku pemberian makan. Edukasi gizi dengan media berupa booklet dan contoh langsung (food sample) akan lebih mudah dipahami oleh subjek penelitian karena menarik perhatian dan tidak membosankan. Hal ini diperlihatkan oleh kedua kelompok melalui peningkatan skor praktik pemberian makan. Menurut ahli indera 75\% hingga 87\% pengetahuan manusia disalurkan melalui indera pandang. Gambar yang terdapat dalam booklet, serta contoh hidangan merupakan stimulus yang mungkin mudah diingat oleh sampel sehingga nilai praktik pemberian makan dapat meningkat. Meskipun demikian, peningkatan skor praktik pemberian makan kelompok intervensi lebih tinggi daripada kelompok kontrol. Keadaan ini dapat dijelaskan adanya penggunaan food sample sebagai media intervensi edukasi gizi. Berdasarkan pengamatan di lapangan, penggunaan food sample lebih menarik daripada hanya sekedar gambar serta memberikan kesan yang lebih baik daripada hanya menggunakan gambar atau booklet.

Pada penelitian ini digunakan food sample yang merupakan pangan lokal yang ada di sekitar. Pangan lokal yang dipilih adalah ikan karena lokasi penelitian terletak dipinggir pantai yang banyak menghasilkan ikan. Hasil penelitian menunjukkan masih kurangnya pemanfaatan pangan lokal oleh keluarga sebelum dilakukan edukasi. Responden ibu lebih memilih untuk memberikan makanan yang mengenyangkan dari pada makanan yang bergizi. Hal ini mengindikasikan responden ibu kurang memperhatikan kandungan bahan makanan yang diberikan pada baduta sehingga asupan kurang dari kebutuhan.

Edukasi gizi kepada balita usia 7 hingga 24 bulan merupakan salah satu intervensi yang dapat diberikan mengingat pada usia tersebut merupakan usia emas kehidupan. Kajian intervensi gizi membuktikan bahwa perbaikan praktik pemberian makan yang berupa peningkatan panjang badan tidak dapat langsung diamati. Berdasarkan penelitian yang telah dilakukan, perubahan dapat diamati pada saat anak tersebut berusia lebih dari 24 bulan yaitu sekitar usia 48 bulan. Adanya catch-up setelah usia 24 bulan merefleksikan ketersediaan makanan, pola konsumsi, komposisi zat gizi yang cukup serta terhindar dari infeksi (Dewi \& Aminah, 2016).

\section{Uji Pengaruh Edukasi Gizi terhadap Praktik Pemberian Makan pada Baduta Stunting}


Agus Sri Banowo dan Yance Hidayat, Pengaruh Edukasi Gizi terhadap Praktik Pemberian Makan Pada Baduta Stunting di Kabupaten Bengkulu Utara

Berdasarkan hasil penelitian, pengaruh praktik pemberian makan keluarga antara kelompok intervensi dan kontrol dapat dilihat pada Tabel 4 sebagai berikut:

Tabel 4. Pengaruh praktik pemberian makan pada baduta stunting

\begin{tabular}{llcccc}
\multicolumn{1}{c}{ Praktik } & $\begin{array}{c}\text { Selisih } \\
\text { Mean }\end{array}$ & SD & SE & $\begin{array}{c}\text { P } \\
\text { Value }\end{array}$ & N \\
\hline Kontrol & 0,125 & 1,884 & 0,211 & 0,000 & 80 \\
Intervensi & 6,050 & 3,946 & 0,441 & & \\
\hline
\end{tabular}

Hasil Uji independen t-test pada praktik pemberian makan antara kelompok intervensi dan kelompok kontrol didapatkan nilai $p$ value 0,000 . Bedasarkan hasil tersebut dapat diartikan bahwa ada pengaruh pemberian edukasi gizi pada kelompok intervensi.

Hasil penelitian Negash et al., (2014); Mulualem et al., (2016); Hardiansyah dan Supriansyah, (2016) serta Kustiani dan Prima, (2018) menunjukkan pemberian edukasi gizi dapat meningkatkan pengetahuan dan praktik ibu dalam pemenuhan nutrisi yang akhirnya dapat meningkatkan status gizi pada anak. Edukasi gizi adalah suatu gabungan strategi pendidikan dengan dukungan lingkungan dan dibuat supaya sasaran dapat memilih makanan dan tindakan yang berkaitan dengan kesehatan dan kesejahteraan. Edukasi gizi juga dapat diartikan sebagai salah satu bagian dari promosi kesehatan pada pendidikan, pendidikan kesehatan bertujuan untuk mengubah atau membentuk perilaku kesehatan (Notoatmojo, 2014).

Semakin bertambah informasi yang didapat ibu dan pengetahuan yang meningkat tentang pemberian makanan, maka semakin baik pula perilaku ibu dalam pemberian makanan yang diberikan ibu kepada anak 6-24 bulan. Tingkat pengetahuan ibu tentang pemberian MP ASI berpengaruh terhadap sikap dan perilaku ibu dalam memilih makanan yang diberikan kepada anaknya. Pengetahuan gizi yang baik yang dimiliki ibu diharapkan mempengaruhi konsumsi makanan yang baik bagi anaknya. Hal ini mampu memperbaiki status gizi ke arah yang lebih baik pula. Pengetahuan gizi ibu memiliki peran penting dalam pembentukan kebiasaan makan anak. Penyuluhan yang diberikan terhadap ibu dapat meningkatkan perilaku ibu dalam perilaku pemberian makanan pada anaknya.

Ketahahanan pangan mengacu pada kemampuan individu atau kelompok dalam pemenuhan akses pangan yang cukup baik dari segi ekonomi maupun fisik, aman, dan bergizi uuntuk memenuhi kebutuahan agar dapat hidup dengan sehat dan baik. Peningkatan tinggi badan atau panjang badan pada balita lebih banyak dipengaruhi oleh pemberian kebutuhan pangan atau zat gizi dalam jangka waktu yang lama. Balita yang tidak mendapatkan pangan atau zat gizi makro maupun mikro yang sesuai dengan kebutuhan secara terus menerus, maka pertumbuhan tinggi atau panjang badannya tidak normal atau pendek.

Praktik pemberian makan memberikan dampak terhadap status gizi baduta. Dimana pemberian makan yang baik sangat penting untuk asupan nutrisi, tidak hanya dari apa yang dimakan sama anak, tapi sikap ibu juga berperan. Misalnya saja ada kehadiran ibu untuk mengawasi makan anak. dengan pemberian makan yang baik maka akan menunjang status gizi anak. Maka dapat dikatakan ibu yang memberikan perhatian dan dukungan terhadap anak dapat memberikan dampak prositif pada keadaan status gizi anak.

\section{SIMPULAN}

Berdasarkan hasil penelitian diketahui bahwa edukasi gizi memberikan pengaruh terhadap praktik pemberian makan keluarga terhadap baduta stunting usia 7-24 bulan. Untuk itu perlu dilaksanakannya pemberian edukasi sebanyak 3 kali dalam sebulan. Petugas kesehatan beserta kader kesehatan harus memastikan bahwa setiap ibu hamil harus mengikuti penyuluhan kesehatan. Setiap ibu harus mengikuti penyuluhan minimal 3 kali sebulan, dan mengobservasi kerumahrumah ibu yang memiliki baduta stunting dan melakukan pengukuran secara terus menerus.

Penelitian ini diharapkan akan berimplikasi untuk penelitian dapat menjadi tambahan ilmu mengenai stunting yang dapat dijadikan acuan untuk mengembangkan penelitian baik dari segi variabel, metode dan jenis penelitian, serta media penelitian yang berkaitan dengan praktik pemberian makan anak stunting usia 7-24 bulan

\section{DAFTAR PUSTAKA}

Alzaheb, R.A., 2016. Factors associated with the early introduction of complementary feeding in Saudi Arabia. International journal of environmental research and public health, 13(7), p.702.

Arini FA, Sofianita NI, Ilmi IM. Pengaruh pelatihan pemberian MP ASI kepada ibu dengan anak Baduta di Kecamatan Sukmajaya Kota Depok terhadap pengetahuan dan perilaku pemberian MP ASI. Jurnal Kedokteran dan Kesehatan. 2017 Aug 18;13(1):80-9.

Coffey D, Deaton A, Drèze J, Spears D, Tarozzi A. Stunting among children: Facts and implications. Economic and Political Weekly. 2013 Aug 24;48(34):68-70.

De Onis M, Branca F. Childhood stunting: a global perspective. Maternal \& child nutrition. 2016 May;12:12-26.

Demirchyan A, Petrosyan V, Sargsyan V, Hekimian K. Predictors of stunting among children ages 0 to 59 months in a rural region of Armenia. Journal of pediatric gastroenterology and nutrition. 2016 Jan 1;62(1):150-6. 
Dewi M, Aminah M. Pengaruh edukasi gizi terhadap feeding practice ibu balita stunting usia 6-24 bulan (the effect of nutritional knowledge on feeding practice of mothers having stunting toddler aged 6-24 months). Indonesian Journal of Human Nutrition. 2016 Jul 1;3(1):1-8.

Fikadu T, Assegid S, Dube L. Factors associated with stunting among children of age 24 to 59 months in Meskan district, Gurage Zone, South Ethiopia: a case-control study. Bmc public health. 2014 Dec;14(1):1-7.

Gibney MJ, Margetts BM, Kearny JM, Arab L. Public Health Nutrition (Gizi Kesehatan Masyarakat). EGC. Jakarta. 2009.

Handayani F, Siagian A, Aritonang EY. Mother's education as A determinant of stunting among children of age 24 to 59 months in North Sumatera province of Indonesia. IOSR J. Humanit. Soc. Sci. 2017;22:58-64.

Hardinsyah M, Supariasa ID. Ilmu gizi teori dan aplikasi. Jakarta: Penerbit Buku Kedokteran EGC. 2016;131.

Heidkamp RA, Ayoya MA, Teta IN, Stoltzfus RJ, Marhone JP. Complementary feeding practices and child growth outcomes in Haiti: an analysis of data from Demographic and Health Surveys. Maternal \& child nutrition. 2015 Oct;11(4):81528.

Kemenkes RI. 2013. Riset Kesehatan Dasar 2013. Badan Penelitian dan Pengembangan Kementerian Kesehatan RI, Jakarta. 2013.

Kemenkes RI. 2018. Upaya percepatan penurunan stunting. In D. G. Masyarakat $(E d)$. Badan Penelitian dan Pengembangan Kementerian Kesehatan RI, Jakarta. 2018.

Kustiani A, Misa AP. Perubahan Pengetahuan, Sikap, dan Perilaku Ibu dalam Pemberian MP-ASI Anak Usia 6-24 Bulan pada Intervensi Penyuluhan Gizi di Lubuk Buaya Kota Padang. Jurnal Kesehatan Perintis (Perintis's Health Journal). 2018 Jun 29;5(1):51-7.

Lemeshow S, Hosmer DW, Klar J, Lwanga SK, World Health Organization. Adequacy of sample size in health studies. Chichester: Wiley; 1990.

Marfuah D, Kurniawati I. Hubungan Pendidikan dan Pekerjaan Ibu Terhadap Pemberian MP-ASI Dini Pada Balita Usia 6-24 Bulan. Jurnal Gizi Stikes PKU Muhamadiyah Surakarta. 2017;15(1):52-5.

Mulualem D, Henry CJ, Berhanu G, Whiting SJ. The effectiveness of nutrition education: Applying the Health Belief Model in child-feeding practices to use pulses for complementary feeding in Southern Ethiopia. Ecology of food and nutrition. 2016 May 3;55(3):308-23.

Musher-Eizenman D, Holub S. Comprehensive feeding practices questionnaire: validation of a new measure of parental feeding practices. Journal of pediatric psychology. 2007 Sep 1;32(8):960-72.

Negash C, Belachew T, Henry CJ, Kebebu A, Abegaz K, Whiting SJ. Nutrition education and introduction of broad bean based complementary food improves knowledge and dietary practices of caregivers and nutritional status of their young children in Hula, Ethiopia. Food and Nutrition Bulletin. 2014 Dec;35(4):480-6.

Notoatmodjo, S., 2010. Promosi kesehatan.

Notoatmodjo, Soekidjo. "Metodologi penelitian kesehatan." (2012).

Purwandini K, Kartasurya MI. 2013. Pengaruh pemberian Micronutrient Sprinkle terhadap perkembangan motorik anak stunting usia 12-36 bulan (Doctoral dissertation, Diponegoro University).

Pérez-Escamilla, Rafael, and Victoria Hall Moran. "The role of nutrition in integrated early child development in the 21st century: contribution from the Maternal and Child Nutrition journal." (2017): 3-6.

Ohyver M, Moniaga JV, Yunidwi KR, Setiawan MI. Logistic regression and growth charts to determine children nutritional and stunting status: a review. Procedia computer science. 2017 Jan 1;116:23241.

Chowdhury MR, Rahman MS, Khan MM. Levels and determinants of complementary feeding based on meal frequency among children of 6 to 23 months in Bangladesh. BMC public health. 2016 Dec;16(1):1-1.

Saaka M, Galaa SZ. Relationships between wasting and stunting and their concurrent occurrence in Ghanaian preschool children. Journal of nutrition and metabolism. 2016 Jan 1;2016.

Sujendran S, Senarath U, Joseph J. Prevalence of stunting among children aged 6 to 36 months, in the eastern province of sri lanka. J Nutr Disorders Ther. 2015;5(1):2161-0509. 